\title{
The Application of LINE as a Multi-Channel Reading Platform: Assist University-Level Students to Learn Chinese as a Second Language
}

\author{
Ping $\mathrm{Xu}$ \\ Business Chinese Department, Faculty of Arts, Assumption University \\ Faculty of Education, International College, Krirk University \\ Thailand
}

\begin{abstract}
In traditional reading class, it is a big challenge for second language learners to read authentic reading materials. This study explored how to use the most popular smartphone application LINE to assist Thai university-level students reading Chinese academic articles in class and after school. In this study, LINE group reading is applied in business Chinese reading class for Chinese major students at Assumption University, Thailand. Also, the study evaluated the effectiveness of using LINE application as a multi-channel reading platform in improving Thai undergraduates' Chinese reading proficiency. The advantages and limitations of using LINE application in business Chinese reading class were also discussed as well. The participants were 16 senior students in Assumption University where the researcher conducted the LINE application reading experiments in Business Chinese class every week. The data were collected by means of the pretest and posttest of reading comprehension, a questionnaire designed by the researcher regarding LINE group reading experiences, informal observation, interview, and the students' feedbacks to LINE application reading experiments. The results indicated that the utilization of LINE application in Chinese reading class offers more opportunities to read extensively and increases the frequency of in \& out of the classroom reading activities. The participants enjoy self-selected reading, multimedia reading, and interactive reading in LINE group more than traditional reading class. By demonstrating the possibilities of using the popular social media tool as a foreign language educational tool, this study can serve as a useful reference material for teaching reading in a digital era.
\end{abstract}

\section{Introduction}

In business reading classroom, it is a noticeable problem that second language learners are reluctant to read business articles, especially those students with gaps in their L2 proficiency. Even some high intermediate to advanced level students also faced difficulty in reading academic materials. The students are often frustrated by the fact that it is too challenging to read business textbooks which are above their level of understanding. It is tricky to find level-appropriate business reading materials.

During traditional reading instruction, the lecturer teaches students reading strategies on how to find keywords, make connections, skim and scan, infer meaning, use context clues, clarify the main idea, identify cause and effect, draw conclusions, summarize the main points. The teacher is the only one who selects reading topics, checks every student's reading assignment, evaluate students' reading skill. The teacher has to spend a lot of time on monitoring every student's reading performance, correcting students' reading errors and giving students reading comments. Students couldn't get the teacher's immediate feedback and receive multiple answers or perspectives from peers. In a traditional teacher-centered class, it is a common phenomenon that students become a passive reader and keep silence in L2 business reading activities, just a passive recipient of teacher's instruction.

Due to the prevalence of social media, the digital generations spend many hours communicating on smartphone messaging apps such as: LINE, Facebook, WeChat, WhatsApp, and Skype, etc. According to the statistics from DI-Marketing [4] online survey, LINE is the leading chat app in Thailand due to the fact it allows people to exchange text messages and make audio \& video call free of charge.

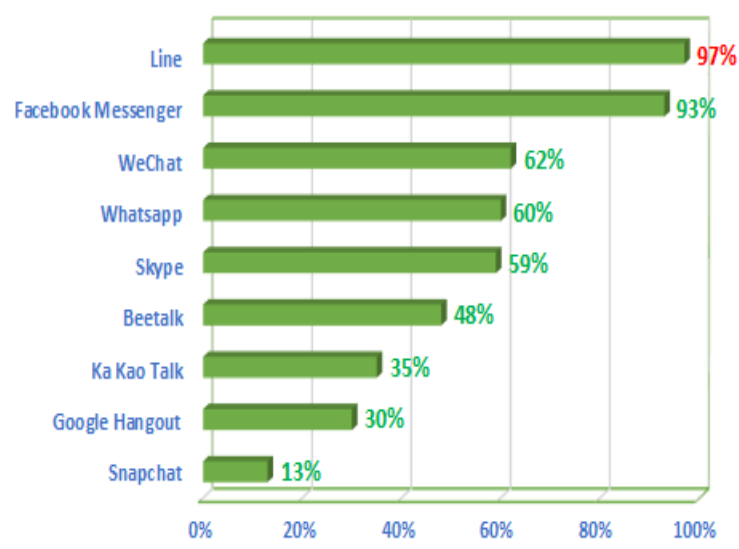

Figure 1.Top Chat Apps in Thailand

[4] 
LINE application offers an opportunity to overcome poor reading skills and increase the frequency of after-class reading activities. However, little research has been done to investigate the effectiveness of using LINE application as a teaching and learning tool to enhance university students' business Chinese reading interests, motivation, initiatives and autonomy. To fill the gap, this study aims to discover the pedagogical values, problems, solutions and implications of applying LINE application as an assisting tool for teaching and learning in Thai university business Chinese reading class.

\section{Literature Review}

\subsection{Social Media Usage for Academic Purpose}

Bangkok University researchers Bogart and Wichadee [20] explored 144 ESL students using LINE app to submit assignment or download learning materials. The results showed the usefulness of LINE-based English class activities. Ru-Chu et al. [19] identified the effects of English spelling learning experience through LINE application for college students. A total of 29 college students participated in a 6-week experiment. The students acquire the ability and the skills in spelling is observed. A positive learning mood is shown through LINE application-based spelling learning.

United Kingdom researcher Li [12] explored tourism and hospitality management students' perceptions of social media applications for formal and informal learning. Beijing University of posts and telecommunication researcher Cheng [11] conducted a three-month study to identify L2 learners' communication strategies. The findings revealed that Chinese engineering students used different kinds of communication strategies to complete academic assignment. China Shenzhen University researcher Jin [14] applied Wechat application in 3 English reading classes for undergraduate English major students. The study offers a successful teaching case: a mobile-assisted English reading class in China. China Youth University for political sciences researcher Zhang [10] explored the application of the flipped class model to reading and writing classes by using WeChat app.

\subsection{Self-selected Reading}

Johnson and Blair [5] discussed the significance of students self-selected reading project in an elementary reading class. The findings indicated that self-selected reading allows student "to value their decision-making ability, fosters their capacity to choose appropriate reading materials, given them confidence, improves reading achievement, and most importantly encourages them in becoming engaged readers." Iran researchers Bonyadi and Zeinalpur [1] conducted a research to identify adult students' perceptions on self-selected and teacher-assigned writing topics. The results showed that students became more inspired to write when using selfselected writing topics. Ho and Choi [8] identified the benefits of self-selecting reading materials. Learners take grater ownership in their leaving process and their motivation to read increase. It was found that shift in power contributed to students' professional development to become a more critical reader.

\subsection{Multi-Media Reading}

Singapore Nanyang Technological University researcher Jose, Spain Baleares Islands University researchers Eduardo and Rafael [3] conducted a study on two groups in $4^{\text {th }}$ grade of secondary education in Spain Agora Portals International School. A multimedia methodology to develop the textual comprehension, properly designed, helps the educational process to be more effective because students make fewer mistakes when answering questions. Researchers Zhou and Yadav [15] investigated the effects of multimedia story reading and questioning on children's literacy skills. A total of 72 participants were randomly assigned to multimedia story reading, multimedia story reading with questioning, paper story reading, and paper story with questioning. The results showed significant interaction of media and questioning on target vocabulary and significant main effect of media for engagement. University Putra Malaysia researchers Alkhasawneh et al. [18] developed a multimedia reading comprehension text to increase students' ability to comprehend the reading text. The result suggested that students who use verbal and pictorial channels in reading comprehension text increased students' achievement in reading comprehension.

\subsection{Interactive Reading}

Patricia et al. [16] pointed out that "reading in a second language involves more than decoding; instead, reading is seen as an interactive process whereby the learner's own background and knowledge contribute to understanding reading material." According to Boston University researcher Mikulecky [2], reading in a second language as "primarily unconscious, interactive process continues until the reader is satisfied with the match between text and prior knowledge, and comprehension has occurred." Shawn [6] identified 
"utilization of the interactive reading model puts more of a responsibility on the teachers to act as facilitators of the reading process rather than monitors of performance."

\section{Methodology}

\subsection{Research Objective}

To explore the pedagogical values of applying LINE application as an assisting teaching and learning tool in business Chinese reading class for L2 learners.

\subsection{Participants}

In this research, the participants were senior students who enrolled in Reading in Business Chinese course, offered at Assumption University of Thailand. It was a three-credit, fifteen-week major elective course in 2/2016 taken by the grade four students from business Chinese department. Their Chinese proficiency level is from intermediate to advanced level. A total of 16 students, 25\% intermediate level (HSK4) students, 25\% advanced level (HSK5) students and 6.25\% (HSK6) high advanced level student.

\subsection{Measure}

This study took place over five month's period of time. Both quantitative and qualitative analysis were used to identify the pedagogical values, problems, solutions and implications of applying LINE application as an assisting tool for teaching and learning in Thai university business Chinese reading class.

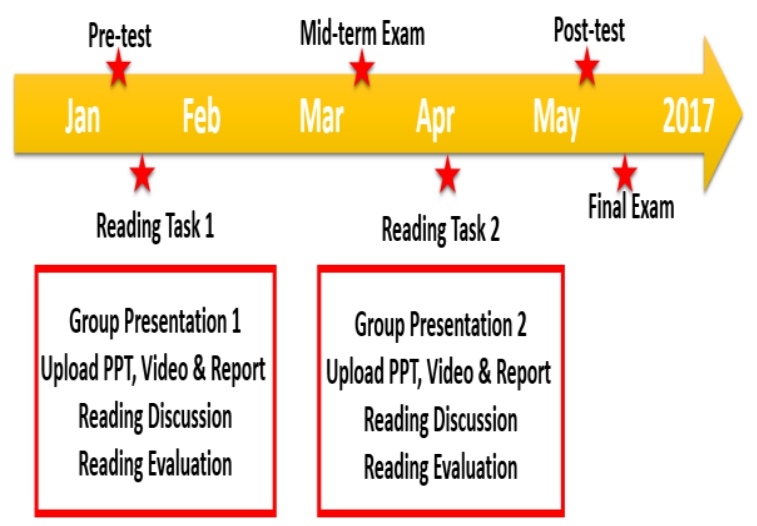

Figure 2. Research Timeline

Three types of data were collected:
(1) the pretest of reading comprehension given at the beginning of the semester and the posttest of reading comprehension given at the end of semester.

(2) a questionnaire designed by the researcher regarding LINE application interactive reading experiences. At the end of semester, the participants were asked to respond to the questionnaire.

(3) informal observations, interviews, and the students' feedbacks to LINE application reading experiments.

All the data were then coded and analyzed by using SPSS analysis.

\section{Findings}

In this study, the researcher divided all students into eight reading groups with two students per group. Business reading topics were selected by each group every week for students to read and discuss. Student self-selected authentic business Chinese reading materials were used in order to increase students' engagement and intrinsic motivation.

Table 1. The Schedule of Business Reading Task I

\begin{tabular}{|c|c|c|}
\hline Date & Topic & Country \\
\hline 日期 & 主题 & 国家 \\
\hline $\begin{array}{l}\text { Jan } 16^{\text {th }}, 2017 \\
\text { 2017年1月16日 }\end{array}$ & $\begin{array}{l}\text { CP Group } \\
\text { 正大集团 }\end{array}$ & $\begin{array}{l}\text { Thailand } \\
\text { 泰国 }\end{array}$ \\
\hline $\begin{array}{l}\text { Jan } 23^{\text {rd }}, 2017 \\
\text { 2017年1月23日 }\end{array}$ & $\begin{array}{l}\text { iPhone } \\
\text { 苹果手机 }\end{array}$ & $\begin{array}{l}\text { America } \\
\text { 美国 }\end{array}$ \\
\hline $\begin{array}{l}\text { Feb } 1^{\text {st }}, 2017 \\
\text { 2017年2月1日 }\end{array}$ & $\begin{array}{l}\text { Facebook } \\
\text { 脸书 }\end{array}$ & $\begin{array}{l}\text { America } \\
\text { 美国 }\end{array}$ \\
\hline $\begin{array}{l}\text { Feb 6 }{ }^{\text {th }}, 2017 \\
\text { 2017年2月6日 }\end{array}$ & $\begin{array}{l}\text { KFC } \\
\text { 肯德基 }\end{array}$ & $\begin{array}{l}\text { America } \\
\text { 美国 }\end{array}$ \\
\hline $\begin{array}{l}\text { Feb } 15^{\text {th }}, 2017 \\
2017 \text { 年2月 } 15 \text { 日 }\end{array}$ & $\begin{array}{l}\text { Wongnai Restaurant } \\
\text { Review Website } \\
\text { Wongnai 餐馆评论网站 }\end{array}$ & $\begin{array}{l}\text { Thailand } \\
\text { 泰国 }\end{array}$ \\
\hline $\begin{array}{l}\text { Feb 20 } 0^{\text {th }}, 2017 \\
2017 \text { 年2月20日 }\end{array}$ & $\begin{array}{l}\text { Tao Kae Noi Crispy } \\
\text { Seaweed 小老板海苔 }\end{array}$ & $\begin{array}{l}\text { Thailand } \\
\text { 泰国 }\end{array}$ \\
\hline 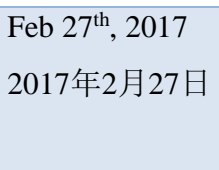 & $\begin{array}{l}\text { Waraporn Steamed Stuffed } \\
\text { Bun } \\
\text { Waraporn 小笼包 }\end{array}$ & $\begin{array}{l}\text { Thailand } \\
\text { 泰国 }\end{array}$ \\
\hline $\begin{array}{l}\text { Feb } 27^{\text {th }}, 2017 \\
2017 \text { 年2月27日 }\end{array}$ & $\begin{array}{l}\text { E-Commerce Billionaire } \\
\text { Jack Ma } \\
\text { 电子商务亿万富翁马云 }\end{array}$ & $\begin{array}{l}\text { China } \\
\text { 中国 }\end{array}$ \\
\hline
\end{tabular}


During the first reading task cycle, the students selected five topics on food business: KFC from USA, CP Group, Tao Kae Noi Crispy Seaweed, Waraporn Salapao Chain, and Wongnai Restaurant Review Website from Thailand. CP group is Thailand's largest food and agriculture company. Tao Kae Noi Crispy Seaweed owner Itthipat is the role model of university students. Itthipat dropped out from the college and started his food business. The top seaweed producer in Thailand made him a youth icon for Thai young man. Although his company's headquarter is in Bangkok, but the young entrepreneur has ambitious to make Tao Kae Noi a global brand. Waraporn Salapao Chain offers Thai versions of Chinese steamed stuffed bun. Wongna.com is Thailand's number one restaurant review website, and functions similarly to Yelp. The last three groups talking about iPhone and Facebook from USA, E-Commerce Billionaire Jack Ma from China respectively.

Table 2. The Schedule of Business Reading Task II

\begin{tabular}{|c|c|c|}
\hline Date & Topic & Country \\
\hline 日期 & 主题 & 国家 \\
\hline Mar 22nd 2017 & Ichitan Drink & Thailand \\
\hline 2017年3月22日 & Ichitan 饮料 & 泰国 \\
\hline Mar 27th 2017 & Huawei Smart Phone & China \\
\hline 2017年3月27日 & 华为手机 & 中国 \\
\hline Mar 29th 2017 & Youtube & America \\
\hline 2017年3月29日 & Youtube 网站 & 美国 \\
\hline Apr 3rd 2017 & UNIQLO Clothes & Japan \\
\hline 2017年4月3日 & 优衣库服装 & 日本 \\
\hline Apr 5th 2017 & Starbucks Coffee & America \\
\hline 2017年4月5日 & 星巴克咖啡 & 美国 \\
\hline Apr 10th 2017 & After You Desert & Thailand \\
\hline 2017年4月10日 & After You 甜点 & \\
\hline May 1st 2017 & Zara Clothes & Spain \\
\hline 2017年5月1日 & 飒拉服装 & 西班牙 \\
\hline May 3rd 2017 & Major Complex Cinema & Thailand \\
\hline 2017年5月3日 & Major Complex影城 & 泰国 \\
\hline
\end{tabular}

During the second business reading task cycle, the students selected three topics on food business: Starbucks Coffee from USA, Ichitan Organic Green Tea and After You Desert from Thailand. The two groups chose reading topics on clothes business: UNIQLO Clothes from Japan and Zara Clothes from Spain. The last three topics selected reading topics on Youtube from USA, Huawei mobile phone from
China, and Major Complex Cinema from Thailand respectively.

LINE application offers a multi-channel learning platform. In this study, eight reading groups are required to complete three kinds of business reading tasks: PPT, Video, and reading report.

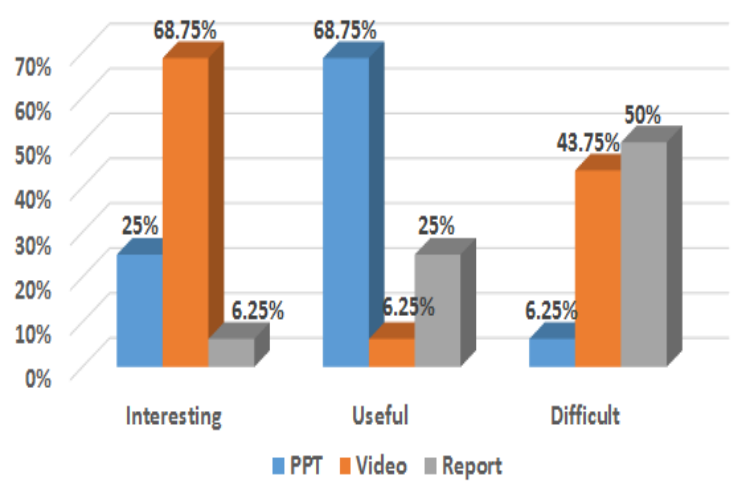

Figure 3. Feedback on Multi Reading Tasks

In terms of students' feedback on reading task types, $68.75 \%$ students preferred video is an interesting digital reading experience because video has sound, voice, subtitle, background music, interviewing people, more attractive than other ways. It can attract everyone to watch because students created their own video based on their own idea to make it more interesting. Also, for making the video, students have to interview people that makes them to improve how to communicate with other people in real life.

$68.75 \%$ students reflected PPT is the most useful digital reading experience because PPT includes a lot of important and useful information on each slide. Group members did the research on the website, made the beautiful PPT, and then sent the group PPT in LINE chat. So other students can read it online and get reading benefits from it.

Regarding the most difficult task, 50\% students pointed out that it is the most difficult thing to write a reading report because the students have to spend a lot of time searching a lot of authentic articles, analyzing the useful information, and summarizing the report according to their personal understanding of the articles. Sometimes, the students have to reread certain key parts of the articles to confirm their understanding of the reading is correct. Finally, they summarize what they read by using new academic vocabulary and grammar in the report to prove that they really understand it.

Also, the students reflected translating Chinese subtitle to match with the video clip was very hard. Because the students' interview dialogs were informal. The subtitle translation must be concise and precise, appearing on the screen for very short time synchronized with the video clip. It required to translate the interview dialogs by using shorter words or simple language. Every subtitle should be short 
enough to comfortable fit on the screen, so the audiences had enough time to read and understand subtitle. In order to elevating the viewing experience, the students had to customize the font, size, color and position of the subtitles, making videos easy to share and understand. Subtitling the whole video clip was very time-consuming.

Table 3. LINE Group Reading Experiences

\begin{tabular}{|l|l|l|}
\hline Item & \multicolumn{1}{|l|}{ Mean } & Std. \\
\hline $\begin{array}{l}\text { Keep the useful business Chinese } \\
\text { reading materials for the later review }\end{array}$ & 4.56 & 0.61 \\
\hline $\begin{array}{l}\text { Discuss interesting business Chinese } \\
\text { articles together }\end{array}$ & 4.44 & 0.61 \\
\hline $\begin{array}{l}\text { Solve business Chinese reading } \\
\text { problems together }\end{array}$ & 4.31 & 0.46 \\
\hline $\begin{array}{l}\text { Increase business Chinese reading skill } \\
\text { Become a critical-thinker }\end{array}$ & 4.31 & 0.46 \\
\hline $\begin{array}{l}\text { Improve business Chinese reading } \\
\text { comprehension }\end{array}$ & 4.13 & 0.43 \\
\hline $\begin{array}{l}\text { Learn real life business Chinese } \\
\text { communication }\end{array}$ & 4.06 & 0.48 \\
\hline $\begin{array}{l}\text { Help to correct business Chinese } \\
\text { reading mistake }\end{array}$ & 4.06 & 0.75 \\
\hline $\begin{array}{l}\text { Share the website link related to } \\
\text { business Chinese reading }\end{array}$ & 3.81 & 0.73 \\
\hline $\begin{array}{l}\text { Overall, it is a meaningful business } \\
\text { Chinese reading experience }\end{array}$ & $\mathbf{4 . 3 8}$ & $\mathbf{0 . 4 8}$ \\
\hline
\end{tabular}

From the questionnaire, the results showed that participants gave the highest store (4.56) to line app's "Keep" function because line could keep the useful business Chinese reading materials for the later review. "Keep" enables students to save and quickly bring up important information without having to scroll through chat history. As a L2 learners, students were benefit from engaging in repetitive Chinese business reading process, because it offers the opportunity to re-think business articles and see more important details they ignored in initial reading. After rereading, students could understand much more unfamiliar business vocabularies and improve business reading fluency accordingly.

The participants gave the second highest store (4.44) to LINE's discussion function. In LINE group chat, online discussion becomes more effective in improving reading comprehension because the process of communication promotes active thinking. When experiencing difficulties related to the business Chinese reading task, students could directly post the reading problems in LINE chat. Most participants consider line groups as a useful and convenient platform for findings answers to their specific questions. (4.31) Some lower level students could ask knowledge-based wh-questions (who, what, when, where). Advanced level students could generate more challenging questions inspire peer's higher thinking skills, such as: analysis, synthesis, clarification or summarization. Overall, LINE group reading is a meaningful experience. (4.38)

Table 4. Business Chinese Reading Test Scores $(\mathrm{n}=16)$

\begin{tabular}{|c|c|c|}
\hline $\begin{array}{c}\text { Pretest } \\
\text { 前测 }\end{array}$ & $\begin{array}{c}\text { Posttest } \\
\text { 后测 }\end{array}$ & $\begin{array}{c}\text { Gain } \\
\text { 进步分数 }\end{array}$ \\
\hline 83.1 & 89.6 & 6.5 \\
\hline
\end{tabular}

Table 5. Business Chinese Reading Test Score by Level

\begin{tabular}{|c|c|c|c|c|}
\hline $\begin{array}{c}\text { Level } \\
\text { 汉语水平 }\end{array}$ & $\begin{array}{c}\text { 人 } \\
\text { 数 }\end{array}$ & $\begin{array}{c}\text { Pretest } \\
\text { 前测 }\end{array}$ & $\begin{array}{c}\text { Posttest } \\
\text { 后测 }\end{array}$ & $\begin{array}{c}\text { Gain } \\
\text { 进步分数 }\end{array}$ \\
\hline $\begin{array}{c}\text { HSK6 } \\
\text { 六级 }\end{array}$ & 1 & 90 & 92.5 & 2.5 \\
\hline $\begin{array}{c}\text { HSK5 } \\
\text { 五级 }\end{array}$ & 4 & 85.0 & 90.6 & 5.6 \\
\hline $\begin{array}{c}\text { HSK4 } \\
\text { 四级 }\end{array}$ & 4 & 85.0 & 90.3 & 5.3 \\
\hline $\begin{array}{c}\text { Others } \\
\text { 其它 }\end{array}$ & 7 & 80.0 & 88.2 & 8.2 \\
\hline
\end{tabular}

Note: HSK refers to Chinese Proficiency Test.

The business Chinese reading test score was used to evaluate the participants' reading development. The scores of sixteen senior students showed the difference between pretest and posttest. The mean of the pretest was 83.1. The mean of the posttest was 89.6. It meant that the mean of the posttest gained 6.5 .

Classified by students' Chinese proficiency level, the pretest and posttest of business Chinese reading comprehension test also have significant differences. The mean of the pretest score of high advanced level (HSK6) students group was 90. The mean of the posttest score of high advanced level (HSK6) students group was 92.5. It meant that the mean of the posttest score gained 2.5. The mean of the pretest score of advanced level (HSK5) students group was 85 . The mean of the posttest score of advanced level (HSK5) students group was 90.6. It meant that the mean of the posttest score gained 5.6. The mean of the pretest score of intermediate level (HSK4) students group was 85 . The mean of the posttest score of intermediate level (HSK4) students group was 90.3. It meant that the mean of the posttest score gained 5.3. For those students who didn't take the HSK test yet, the mean of the pretest score was 80 , and the posttest score was 88.2. It meant that the mean of the posttest score gained 8.2. From the result above, it could be concluded that LINE application significantly improved students' business Chinese reading comprehension. 


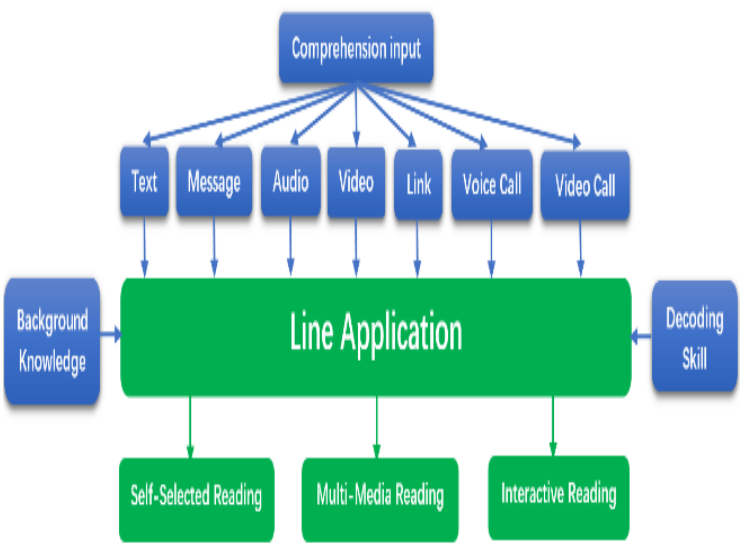

Figure 3. Model of LINE App Reading Process

After five months, students' business Chinese reading task history and interview record were collected and analyzed through content analysis method. The most cited reply was LINE application could easily capture students' attention, engaging them in multi-media business Chinese reading activities, such as: text, message, graphics, animation, audio, video, website link, voice call or video call. Through LINE application reading, students read many authentic articles, meet large numbers of new vocabularies, and diverse grammar patterns that are not taught in textbooks. Students' reading comprehension is easy to be impaired by a limited reading vocabulary after encountering academic vocabulary that is unfamiliar to them. Students need multimedia support for vocabulary enrichment and reading comprehension. Multimedia enhance vocabulary acquisition, reading comprehension, and reading engagement.

\section{Conclusions}

This research reports a fifteen-week study in a fourth-grade business Chinese reading classroom in Thailand. The objective of this research is to investigate the pedagogical values of applying LINE application as an assisting teaching and learning tool. Classroom observations at the beginning of the semester showed that some students unwilling to engage in business Chinese reading activities. In foreign language business reading course, one of the most challenging tasks is the selection of appropriate business reading materials. In order to increase students' engagement and intrinsic reading motivation, the researcher gave the group members freedom to choose their own reading adventure. In this study, students could read self-selected, highinterest, level-appropriate business Chinese reading articles. After fifteen-week's experiment, the interview results showed that self-selected business Chinese reading materials satisfied students' reading curiosity and critical thinking skills. Most students changed from passive readers to engaged readers who enjoyed the pleasant and satisfying reading experiences.

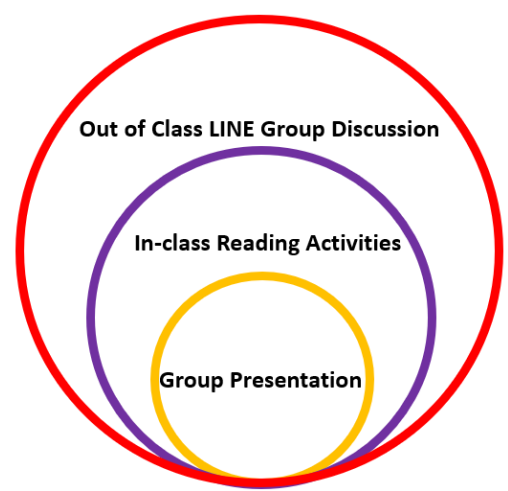

Figure 4.In \& Out of Class LINE Reading Activities

LINE application offers an opportunity to read updated academic articles and increases the frequency of in \& out of the classroom reading activities. Students spent more time on LINE reading. The digital generation improved reading efficiency through technological innovations unconsciously. The students are free to choose their favorite reading topics and share their group presentation, video clips, and reading reports with all the class. Students could get the teacher's immediate feedback or receive multiple answers or perspectives from peers. Shared reading provides struggled readers the necessary support and increase all students' engagement Some students will never forget the reading group discussion experiences that their partners shared with them in LINE application. In this way, the LINE reading group creates a very good environment that encourages and rewards reading academic articles, making academic reading fun and meaningful.

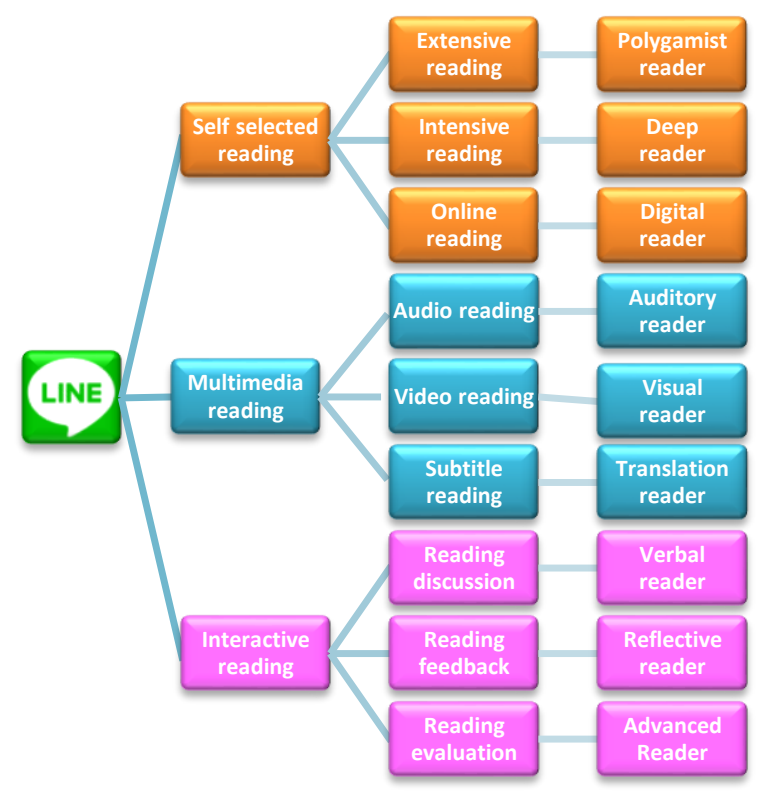

Figure 5.Multi-Channel Reading Platform 
In this study, the researcher utilized LINE app as a multi-channel reading platform. Students were divided into eight reading groups. Before each group chose their favorite business reading topics, the students have to read all the related native reading materials extensively. The more extensive reading, the more target language adventure, increasing students' academic vocabularies quickly. And then focused on one or two good articles for intensive reading, deep reading, and critical thinking.

There are individual differences in L2 readers. Some students are visual readers, benefit from PPT slide reading, video interview/subtitle reading, written report, or website link reading. Some students are auditory reader, benefit from group reading presentation or LINE group discussion. Some students are translation reader, if they read subtitle they understand the meaning. To meet the diverse needs of L2 readers, the researcher applied the multimedia technology to assist the reading instruction. LINE groups offer opportunities to show what the students know through shared reading, guided reading, oral report, written report, LINE group discussion, PPT presentation, video presentation, and other creative reading activates. Also, LINE app provides a rich interactive language environment for peer learning and peer networking. This study suggested LINE reading platform is helpful in improving students' reading fluency and comprehension.

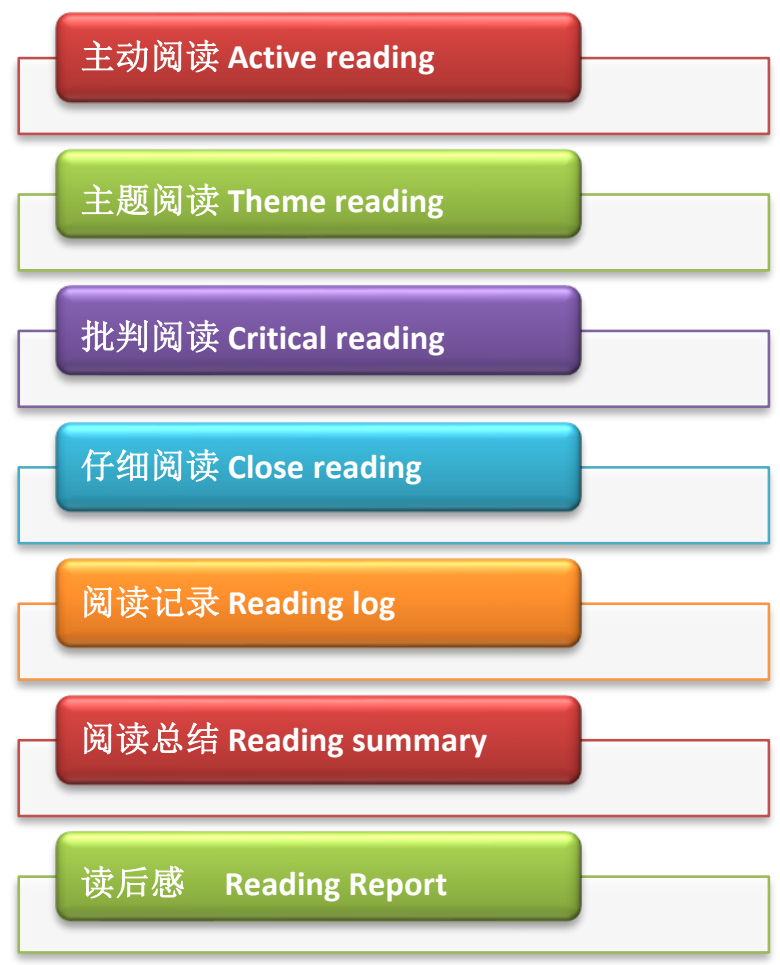

Figure 6. Deep Reading Strategies

Thanks for the advancement of high technology, nowadays a smartphone seems like a movable library. The traditional paper reading was replaced by fingertip reading. Students browse their default search engine to quickly scan key words, the article title, subtitle, abstract, chapter headings, introductions, conclusions, tables, figures, etc. Actually, we can call it fast food reading, surface reading, or fragmental reading. In this way, students read more quickly, but less deeply, only learn the superficial knowledge from the reading material. There is no necessary relationship between reading quantity and reading quality. In this study, the researcher tried to teach students the diverse deep reading strategies such as: active reading, theme reading, problem-based reading, critical reading to close reading. After deep reading, students wrote reading $\log$, reading summary and reading report after deep reading. It is a big challenge to train L2 learners to become a deep reader and focused learner in digital era.

In our regular reading class, it is normal phenomenon there are a lot of different ability students. A few students are good at reading authentic articles, while the other students only read but don't understand at all. A few students finished the reading assignments very quickly, while the other students only just read the introduction part.

\section{Poor reader:}

- $\quad$ struggling with authentic reading

- low target language proficiency

- few academic vocabularies

- read slowly

- dislike reading

- low reading scores

- no background knowledge

- $\quad$ surface reading

- poor decoder

- basic comprehension skills

- $\quad$ skip over challenging reading assignments

- need more reading assistance from the teacher

- compulsory reading task

- $\quad$ passive reading

\section{Good reader:}

- $\quad$ good at reading authentic articles

- $\quad$ high target language proficiency

- many academic vocabularies

- read fast

- like reading

- high reading scores

- connecting new information to prior knowledge

- deep reading

- good decoder

- $\quad$ sophisticated comprehension skills 
- $\quad$ finish challenging reading assignments without difficulty

- dominate the reading discussion

- autonomous reading

- compulsory reading task and optional reading task

- $\quad$ active reading

It is difficult to provide effective reading materials for all students. The reading materials maybe too easy for some students, but too difficult for other students. The advanced students feel bored and waste time if the teacher spends a lot of time explaining to the weak students. At LINE reading group, the teacher could assign the advanced student as an academic peer tutor. Weak students could take advantage of peer support. Peer tutors reinforce their own reading comprehension by instructing other peer students. This became a win-win situation.

\section{Suggestions}

Although LINE app is usually used for social interaction and networking. LINE app plays a significant role in foreign language teaching and learning process. The educators could use LINE app to create an effective target language immersion environment for students to frequently use the target language practice reading comprehension. However, some participants reflected facing digital distractions during reading authentic articles. Therefore, the future research could focus on how to fight digital distraction and enhance reading efficiency. Students grow up with smartphone. It's a big challenge for smartphone generation to concentrate on academic reading task because of diverse digital distractions, maybe a WeChat message, a Facebook update, an Instagram picture, a new Email is coming, an overload of information waiting for students to read. The students think they could balance academic reading task and social network life at the same time. The students' brain switches back and forth between LINE, WeChat, Facebook, Instagram, Email, etc. The overload information from the internet occupied the students' limited attention. The diverse online attractions deteriorate students' attention span and exhaust brain as well. The students will quickly transfer their attention to what's happening right now, without thinking what they have read just now. Therefore, the efficiency of academic reading is hugely decreased by the constant digital interruption. So, future researchers could focus on how to help smartphone generation overcome digital distractions and enhance their academic reading comprehension.

\section{References}

[1] Bonyadi, A., and Zeinalpur, S., "Perceptions of Students Towards Self-selected and Teacher-assigned Topics in EFL Writing", Procedia - Social and Behavioral Sciences 98, Longman, 2014, pp. 385-391.

[2] Mikulecky, B.S., (2008) 'Teaching Reading in a Second Language', Pearson Education, Longman; http://www.longmanhomeusa.com/content/FINALLO\%20RES-Mikulecky-Reading\%20Monograph\%20.pdf (18 February 2018).

[3] Jose, D.G.M., Eduardo, R., and Rafael, J., "Multimedia and Textual Reading Comprehension: Multimedia as Personal Learning Environment's Enriching Format", Journal of New Approaches in Educational Research, Vol6, No 1 (2017), https://naerjournal.ua.es/article/ view/v6n1-1 (Access date: 18 February 2018).

[4] DI-Marketing. (2016) 'Study about Chat App Usage in THAILAND'; http://www.di-onlinesurvey.com (Access date: 18 February 2018).

[5] Johnson, D., Blair, A., (2003), 'The Importance and Use of Student Self-Selected Literature to Reading Engagement in an Elementary Reading Curriculum' Reading Horizons; http://scholarworks.wmich.edu/cgi/ viewcontent.cgi? article $=1155 \&$ context $=$ reading_horizons (Access date: 18 February 2018).

[6] Shawn, D.M., (2012), 'Utilizing the Interactive Reading Model in a Continuing Education Course', MA TESOL Collection, http://digitalcollections.sit.edu/cgi/ viewcontent.cgi?article $=1541 \&$ context=ipp_collection (Access date: 18 February 2018).

[7] Cerda, F.P.D.L., (2016) 'The Design of a Theme-Based and Genre-Oriented Strategic Reading Course to Improve Students', How Journal; https://howjournalcolombia.org/ index.php/how/article/view/143 (Access date: 18 February 2018).

[8] Ho, H., Choi, C.C., (2005) 'Benefit of Self-Selecting Reading Materials?', Academic Exchange Quarterly, https://www.questia.com/library/journal/1G1136071117/benefit-of-self-selecting-reading-materials (Access date: 18 February 2018).

[9] Korbey, H., (2014) 'Can Students 'Go Deep' with Digital Reading?'; https://ww2.kqed.org/mindshift/ 2014/09/09/can-students-go-deep-with-digital-reading/ (Access date: 18 February 2018).

[10] Zhang, J., "Flipped Class Mode' Applied to Reading an Writing Class with WeChat App", Sino-US English Teaching, June 2017, 14(6), pp. 360-365.

[11] Cheng, L., "A Study of Chinese Engineering Students' Communication Strategies in a Mobile-Assisted Professional Development Course", The Eurocall Review, European Association for Computer Assisted Language Learning, Vol 24. No 2. September 2016, pp. 195-202. 
[12] Li, L., "Are Social Media Applications a Facilitator or Barrier to Learning for Tourism and Hospitality Management Students?", Research in Hospitality Management, Netherlands, 2016, pp. 195-202.

[13] Larkin, M., and Flash, D., 'Digital Reading: Challenges and Opportunities', Berkeley Center for Teaching \& Learning; http://teaching.berkeley.edu/digitalreading-challenges-and-opportunities (Access date: 18 February 2018)

[14] Jin, N., "Mobile-Assisted Language Learning: Using WeChat in an English Reading Class", Emerging Technologies for Education, Lecture Notes in Computer Science, vol 10676, Springer, 2017, pp 500-506.

[15] Zhou, N., and Yadav, A., "Effects of Multimedia Story Reading and Questioning on Preschoolers' Vocabulary Learning, Story Comprehension and Reading Engagement", Educational Technology Research and Development, Springer, December 2017, 65(2), pp15231545.

[16] Patricia. L.C., Devine, J., and Eskey, D.E., 'Interactive Approaches to Second Language Reading', Cambridge University Press, UK, April 1988; http://www.cambridge.org/us/cambridgeenglish/catalog/tea cher-training-development-and-research/interactiveapproaches-second-language-reading/interactiveapproaches-second-language-reading-1 (Access date: 18 February 2018)

[17] Schoonmaker, R.G., "A Blended Learning Approach to Reading Circles for English Language Learners", Second Language Studies, 33(1), Fall 2014, pp.1-22.

[18] Alkhasawneh, S., Rahman, F.A., Ayub, A.F.M. and Daud, S. M., "Developing Multimedia Text for Reading Comprehension Based on Cognitive Theory of Multimedia Teaching", International Journal of Innovative Ideas, 12(4) November 2012, pp11-19.

[19] Ru-Chu, S., Chunyi, L., Tsai-Feng, C., "Effects of English Spelling Learning Experience through a Mobile LINE App for College Students", Procedia - Social and Behavioral Sciences, ELSEVIER, 12 February 2015, vol 1174, pp 2634-2638.

[20] Bogart, W. V. D., and S. Wichadee, "Exploring Students' Intention to Use Line for Academic Purposes Based on Technology Acceptance Model", Open Journal System, (2015); http://www.irrodl.org/index.php/irrodl/ article/view/1894/3344 (Access date: 18 February 2018) 